\title{
COWPEA RESPONSE TO PHOSPHORUS AND ZINC ${ }^{1}$
}

\author{
FRANCISCO DE BRITO MELO ${ }^{2 *}$, EDSON ALVES BASTOS ${ }^{2}$, MILTON JOSÉ CARDOSO² ${ }^{2}$ VALDENIR QUEIROZ \\ RIBEIRO $^{2}$
}

\begin{abstract}
Low grain yield of cowpea is influenced by several production factors, especially inadequate soil fertilization, in particular, phosphorus application. Tropical soils have low phosphorus and zinc levels due to either the source material or the absence of fertilization, which restricts cowpea grain yield; besides of that, zinc deficiency is accentuated with phosphor application. This study aimed to evaluate the effect of fertilization with phosphorus and zinc on cowpea yield. Two experiments were conducted, one with 'BRS Guariba' cultivar and another with 'BRS Aracê' cultivar. Both of them were performed on a medium-texture dystrophic Yellow Latosol (Oxisol), in the city of Magalhães de Almeida, Maranhão state (Brazil), in 2015. The experimental design was a randomized complete block in a $4 \times 4$ factorial scheme, using four doses of phosphorus $(0,40,80$, and $\left.120 \mathrm{~kg} \mathrm{P}_{2} \mathrm{O}_{5} \mathrm{ha}^{-1}\right)$, and four of zinc $\left(0,2,4\right.$, and $\left.6 \mathrm{~kg}_{\text {of }} \mathrm{Zn} \mathrm{ha}^{-1}\right)$. There was an interaction between these minerals $(\mathrm{p}<0.01)$. Maximum grain yields of $1,376 \mathrm{~kg} \mathrm{ha}^{-1}$ and $2,165 \mathrm{~kg} \mathrm{ha}^{-1}$ were obtained at doses of $118 \mathrm{~kg}$ $\mathrm{P}_{2} \mathrm{O}_{5} \mathrm{ha}^{-1}$ and $0.9 \mathrm{~kg}$ zinc ha ${ }^{-1}$ for 'BRS Guariba', and $120 \mathrm{~kg} \mathrm{P}_{2} \mathrm{O}_{5} \mathrm{ha}^{-1}$ and $3.1 \mathrm{~kg}$ zinc ha ${ }^{-1}$ for 'BRS Aracê', respectively. The production component of greatest influence on grain yield was the number of pods per plant, with average values of 6 and 10 for 'BRS Guariba' and 'BRS Aracê' cultivars, respectively. The mean correlation coefficient was $0.82(\mathrm{p}<0.01)$.
\end{abstract}

Keywords: Vigna unguiculata. Mineral nutrition. Dry grain yield. Phosphor x zinc. Interaction.

\section{RESPOSTA DO FEIJÃO-CAUPI À APLICAÇÃO DE FÓSFORO E ZINCO}

RESUMO - A baixa produtividade de grãos do feijão-caupi é influenciada por vários fatores do processo produtivo, principalmente a inadequada fertilização do solo, em especial a fosfatagem. Os solos tropicais apresentam baixos teores de fósforo e de zinco, seja em função do material de origem ou pela ausência de adubação, o que restringe a produtividade do feijão-caupi. A deficiência de zinco se acentua em função da aplicação de fósforo. Este trabalho objetivou avaliar o efeito da adubação com doses de fósforo e zinco na produção de feijão-caupi. Foram conduzidos dois experimentos, sendo um com a cultivar 'BRS Guariba' e o outro com a cultivar 'BRS Aracê', ambos em um Latossolo Amarelo Distrófico de textura média, no município de Magalhães de Almeida, Maranhão, ano 2015, em delineamento experimental de blocos casualizados, em esquema fatorial $4 \times 4$, utilizando quatro doses de fósforo $\left(0 ; 40 ; 80\right.$ e $120 \mathrm{~kg} \mathrm{de}_{2} \mathrm{O}_{5}$ ha $\left.{ }^{-1}\right)$ e quatro de zinco $(0$; 2; 4 e $6 \mathrm{~kg}$ de zinco ha $\left.{ }^{-1}\right)$. Houve interação entre esses minerais $(\mathrm{p}<0,01)$ e foram obtidas produtividades máximas de $1.376 \mathrm{~kg} \mathrm{ha}^{-1}$ e de $2.165 \mathrm{~kg} \mathrm{ha}^{-1}$ com aplicações de doses de $118 \mathrm{~kg} \mathrm{de}_{2} \mathrm{O}_{5}$ ha ${ }^{-1}$ e de $0,9 \mathrm{~kg}$ de

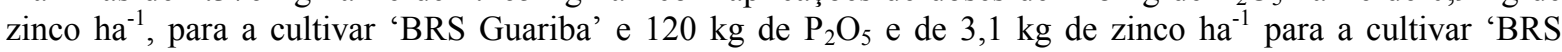
Aracê', respectivamente. $\mathrm{O}$ componente de produção que mais influenciou a produtividade de grãos foi o número de vagens por planta, com valores médios de 6 e 10 para as cultivares 'BRS Guariba' e 'BRS Aracê', respectivamente, e coeficiente de correlação médio de $0,82(p<0,01)$.

Palavras-chave: Vigna unguiculata. Mineral nutrition. Produtividade de grãos secos. Interação fósforo x zinco.

\footnotetext{
${ }^{*}$ Corresponding author

${ }^{1}$ Received for publication in 08/23/2016; accepted in 04/10/2017.

Paper approved from IV CONAC 2016.

${ }^{2}$ Embrapa Meio-Norte, Teresina, PI, Brazil; francisco.brito@embrapa.br, edson.bastos@embrapa.br, milton.cardoso@embrapa.br, valdenir.queiroz@embrapa.br.
} 


\section{INTRODUCTION}

Brazilian soils are mostly deficient in phosphorus, and its addition to correct deficiencies, associated with $\mathrm{pH}$ elevation by liming, are fundamental practices to increase the productivity of annual crops; however, they may induce zinc deficiency (FAGERIA, 1984; FAGERIA, 2000).

Phosphorus is a macronutrient extracted in less quantity by cowpea but is the most limiting element for crop productivity, in most Brazilian soils (SAMPAIO, BRASIL, 2009).

Brazilian agriculture has been undergoing great technological changes and, in addition, the globalization of agribusiness has provoked reflections in the productive chain of several crops, especially those that depend on the use of a large input volume, notably fertilizers and agricultural pesticides. These crops have a higher production cost each year and, as a result, producers have sought new options for their productive arrangements. Cowpea cultivation is observed to be expanding to the Cerrado region, the North, Northeast, and Center-West, where it is incorporated into the productive arrangements as the second harvest after the soybean and corn crops, and in some as the main culture. In the Cerrado region, mainly when it is cultivated in the form of the second harvest, the cowpea has a very competitive cost, a factor that has increased the producers' interest in the culture. The supply of a standardized, high quality product in quantity and with regularity has aroused the interest of agroindustries from other regions and is contributing to the opening of new markets for this culture.

In a study conducted by Silva et al. (2010) in dystro-cohesive Yellow Latosol (Oxisol) in Roraima, using the cowpea cv. precocious 'Pretinho 1', different phosphorus doses $(0,30,60$, 90 , and $\left.120 \quad \mathrm{~kg} \quad \mathrm{P}_{2} \mathrm{O}_{5} \mathrm{ha}^{-1}\right)$ were evaluated under different application modes. The yield of $943.52 \mathrm{~kg} \mathrm{ha}^{-1}$ was reached with a broadcast application of $90 \mathrm{~kg} \mathrm{P}_{2} \mathrm{O}_{5} \mathrm{ha}^{-1}$.

Cowpea yield was analyzed in an experiment conducted in a medium-textured dystrophic Yellow Latosol (Oxisol) under different phosphorus doses in Boa Vista, RR. The yield components grain number and pod length were significantly affected by phosphorus doses. Maximum agronomic efficiency was obtained with the application of $120 \mathrm{~kg} \mathrm{P}{ }_{2} \mathrm{O}_{5} \mathrm{ha}^{-1}$, with grain yield of $1,343 \mathrm{~kg} \mathrm{ha}^{-1}$ (OLIVEIRA et al., 2011).

Coutinho et al. (2014) evaluated the efficiency of phosphate fertilization in cowpea grown in the state of Pará. The authors observed phosphate fertilization had a positive influence on all variables evaluated, and grain yield increased as they applied high $\mathrm{P}_{2} \mathrm{O}_{5}$ doses, not reaching the point of maximum grain yield.

The effect of phosphate fertilization on cowpea was evaluated by Benvindo (2012), using different doses of phosphorus (0, 50, 100, 150, 200, and $300 \mathrm{~kg} \mathrm{ha}^{-1}$ ) in Bom Jesus, PI. The increase of phosphorus levels in the soil influenced foliar concentrations of phosphorus and zinc, linearly increasing these nutrients' leaf contents, and reflecting on the nutrient content of legume seed. The crop maximum grain yield was $1,319 \mathrm{~kg} \mathrm{ha}^{-1}$, obtained in the dose of $168 \mathrm{~kg} \mathrm{P}_{2} \mathrm{O}_{5} \mathrm{ha}^{-1}$.

As for micronutrients, zinc is an element whose deficiency symptoms are frequently observed in crops grown on tropical soils. Furthermore, liming and phosphate fertilization, which are essential practices to increase crop productivity, are indirect causers of zinc deficiency (ROSAL, 2013). Given the importance of phosphorus and zinc, these nutrients must be evaluated alone and together, for although the interaction between them is well mentioned in the literature for several crops, there is a noticeable scarcity of information on cowpea.

This study aimed to evaluate the effect of fertilization with phosphorus and zinc on cowpea production.

\section{MATERIAL AND METHODS}

The experiment was carried out from $03 / 24$ to 05/30/2015 at the Catuai Cajui farm, Magalhães de Almeida, MA, in an area of Cerrado vegetation with a latitude of $03^{\circ} 20^{\prime} 56^{\prime \prime} \mathrm{S}$, longitude of $42^{\circ} 19^{\prime} 42^{\prime \prime} \mathrm{W}$ and altitude of $103 \mathrm{~m}$. Rainfall during the trial period was $293 \mathrm{~mm}$.

The initial soil characterization was performed for samples taken from the $0-20 \mathrm{~cm}$ layer. It consisted of $\mathrm{pH}$ in $\mathrm{H}_{2} \mathrm{O}=5.4$; $\mathrm{H}+\mathrm{Al}=42 \mathrm{mmol}_{\mathrm{c}} \mathrm{dm}^{-3} ; \mathrm{K}^{+}=1.4 \mathrm{mmol}_{\mathrm{c}} \mathrm{dm}^{-3} ;$ $\mathrm{Al}^{-3}=1.0 \mathrm{mmol}_{\mathrm{c}} \mathrm{dm}^{-3} ; \mathrm{Ca}^{2+}=31 \mathrm{mmol}_{\mathrm{c}} \mathrm{dm}^{-3} ;$ $\mathrm{Mg}^{2+}=14 \mathrm{mmol}_{\mathrm{c}} \mathrm{dm}^{-3}$; organic matter $=31 \mathrm{~g} \mathrm{dm}^{-3}$; $\mathrm{P}($ Mehlich $)=4 \mathrm{~g} \mathrm{dm}^{-3}$; base saturation $=52.5 \%$; $\mathrm{Zn}=1.0 \mathrm{mg} \mathrm{dm}{ }^{-3}$; sand fraction $=707 \mathrm{~g} \mathrm{~kg}^{-1}$; silt fraction $=62 \mathrm{~g} \mathrm{~kg}^{-1}$; and clay fraction $=231 \mathrm{~g} \mathrm{~kg}^{-1}$. The method for soil physical and chemical analysis was based on Embrapa (1999).

A randomized block design was used with treatments arranged in a $4 \times 4$ factorial design, that is, four phosphorus levels $\left(\begin{array}{llll}0.0 & 40.0 & 80.0 \text {, and }\end{array}\right.$ $\left.120.0 \mathrm{~kg} \mathrm{P} \mathrm{P}_{2} \mathrm{O}_{5} \mathrm{ha}^{-1}\right)$, and four zinc levels $(0.0,2.0$, 4.0 , and $6.0 \mathrm{~kg}$ of $\mathrm{Znha}^{-1}$ ), in the form of triple superphosphate $\left(45 \% \mathrm{P}_{2} \mathrm{O}_{5}\right)$, and zinc sulfate $(20 \%$ $\mathrm{Zn}$ ), respectively. Two trials were used, one with 'BRS Guariba' cultivar, and the other with 'BRS Aracê', both with three replicates. The experimental unit consisted of six 5-meter rows spaced at $0.5 \mathrm{~m}$, with a density of five plants $\mathrm{m}^{-1}$.

A foundation fertilization was carried out with the doses of $\mathrm{P}_{2} \mathrm{O}_{5}$ (treatments), zinc (treatments), and potassium (40 $\left.\mathrm{kg} \mathrm{ha}^{-1}\right)$. Fertilizer distribution was done manually, in parallel furrows with $0.15 \mathrm{~m}$ of depth and distance of $0.10 \mathrm{~m}$ from the 
planting rows. Nitrogen fertilization was carried out as topdressing (40 $\mathrm{kg}$ of $\mathrm{N} \mathrm{ha}^{-1}$ ), at flowering.

Plant nutritional status was ascertained by determining phosphorus and zinc contents in plant tissue. In addition, at $\mathrm{R}_{2}$, the third trifoliolate leaf from plant apex was sampled from twenty plants per treatment in the experimental unit net area. Foliar tissue samples were oven dried at $65^{\circ} \mathrm{C}$ for 72 hours after harvested, identified, properly washed, and later milled. Nutrient extraction was carried out by nitro-perchloric digestion. Phosphorus contents were determined by the colorimetric method in a UV-visible spectrophotometer, and zinc contents were determined by atomic absorption spectrophotometry.

Seed phosphorus and zinc contents were also evaluated, and the analyses were carried out following the same method used for the leaf tissue analysis, using grains of 10 pods/treatment, sampled in the net area of each experimental unit, at the end of the culture cycle.

The variables evaluated were DGY (dry grain yield), corrected for $13 \%$ moisture $\left(\mathrm{kg} \mathrm{ha}^{-1}\right)$, NGP (number of grains per pod), 100GM (100-grain mass), and NPP (number of pods per plant). The NPP and NGP data were transformed to $\sqrt{\mathrm{x}}$ in order to meet the assumptions of the analysis of variance.

Analysis of variance and polynomial regression were performed using computer software
(SAS INSTITUTE, 2008). Response functions were then adjusted by calculating the $\mathrm{P}_{2} \mathrm{O}_{5}$ and zinc doses, which provided the maximum technical efficiencies for each cowpea cultivar evaluated (ZIMMERMANN (2004).) The significance levels of all coefficients of regression were tested by applying the t-test, and using the ${ }^{* * *}: \mathrm{p} \leq 0.001,{ }^{* * *}: 0.001<\mathrm{p} \leq$ $0.01,{ }^{*}: 0.01<\mathrm{p} \leq 0.05,{ }^{\circ}: 0.05<\mathrm{p} \leq 0.10$ and $^{\Delta}: 0.10<$ $\mathrm{p} \leq 0.15$.

\section{RESULTS AND DISCUSSION}

There were significant interactions $(p<0.01)$ for grain yield and number of pods per plant in the two cowpea cultivars evaluated, as a result of the application of phosphorus and zinc (Table 1).

Maximum grain yields ( $13 \%$ moisture) of $1,376 \mathrm{~kg} \mathrm{ha}^{-1}$ were obtained, with the response function: $\mathrm{DGY}=687.19+44.91^{\mathrm{O}} \mathrm{Zn}-9.24 * \mathrm{Zn}^{2}+$ $11.36^{* * *} \mathrm{P}-0.246^{\Delta} \mathrm{ZnP}-0.047^{* * *} \mathrm{P}^{2} \mathrm{R}^{2}=0.84^{* *}$, and $2,165 \mathrm{~kg} \mathrm{ha}{ }^{-1}$, having as a response function DGY $=627.82+75.55^{*} \mathrm{Zn}-12.25^{*} \mathrm{Zn}^{2}+$ $15.02^{* * *} \mathrm{P}-0.023^{\circ} \mathrm{P}^{2} \mathrm{R}^{2}=0.89^{* *}$, with applications of doses of $118 \mathrm{~kg} \mathrm{P}_{2} \mathrm{O}_{5} \mathrm{ha}^{-1}$, and $0.9 \mathrm{~kg}_{\text {zinc ha }}{ }^{-1}$ for the 'BRS Guariba' cultivar (semi-upright growth) (Figure 1A), and $120 \mathrm{~kg} \mathrm{P}_{2} \mathrm{O}_{5} \mathrm{ha}^{-1}$, and $3.1 \mathrm{~kg}$ zinc ha ${ }^{-1}$ for the 'BRS Aracê' cultivar (semi-prostate growth) (Figure 1B), respectively.

Table 1. Summary of variance analysis for grain yield $\left(\mathrm{kg} \mathrm{ha}^{-1}\right)$, pod number per plant (NPP), grain number per pod (NGP), and 100-grain mass (100GM).

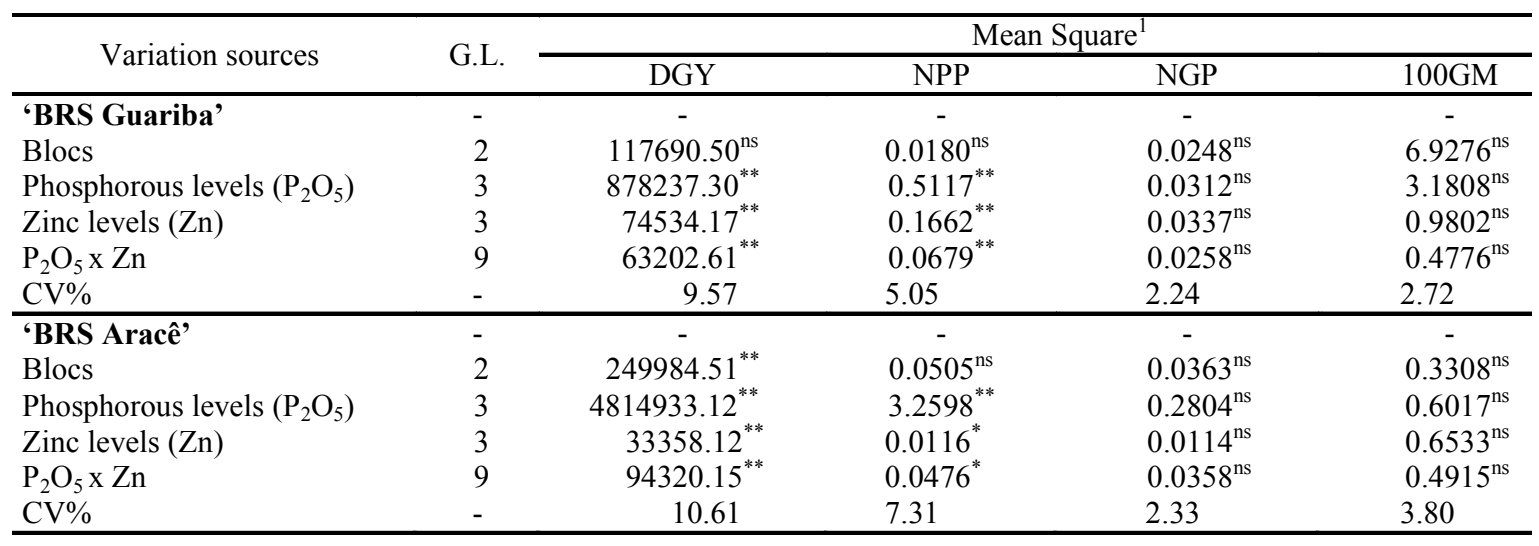

${ }^{1}$ NPP and NGP: data transformed to $\sqrt{\mathrm{x}} \cdot{ }^{* *}: 0,001<\mathrm{p} \leq 0.01 ;{ }^{*}: 0.01<\mathrm{p} \leq 0.05 ;{ }^{\text {ns }}$ : non-significant $(\mathrm{p}>0.05)$ by the F test. 

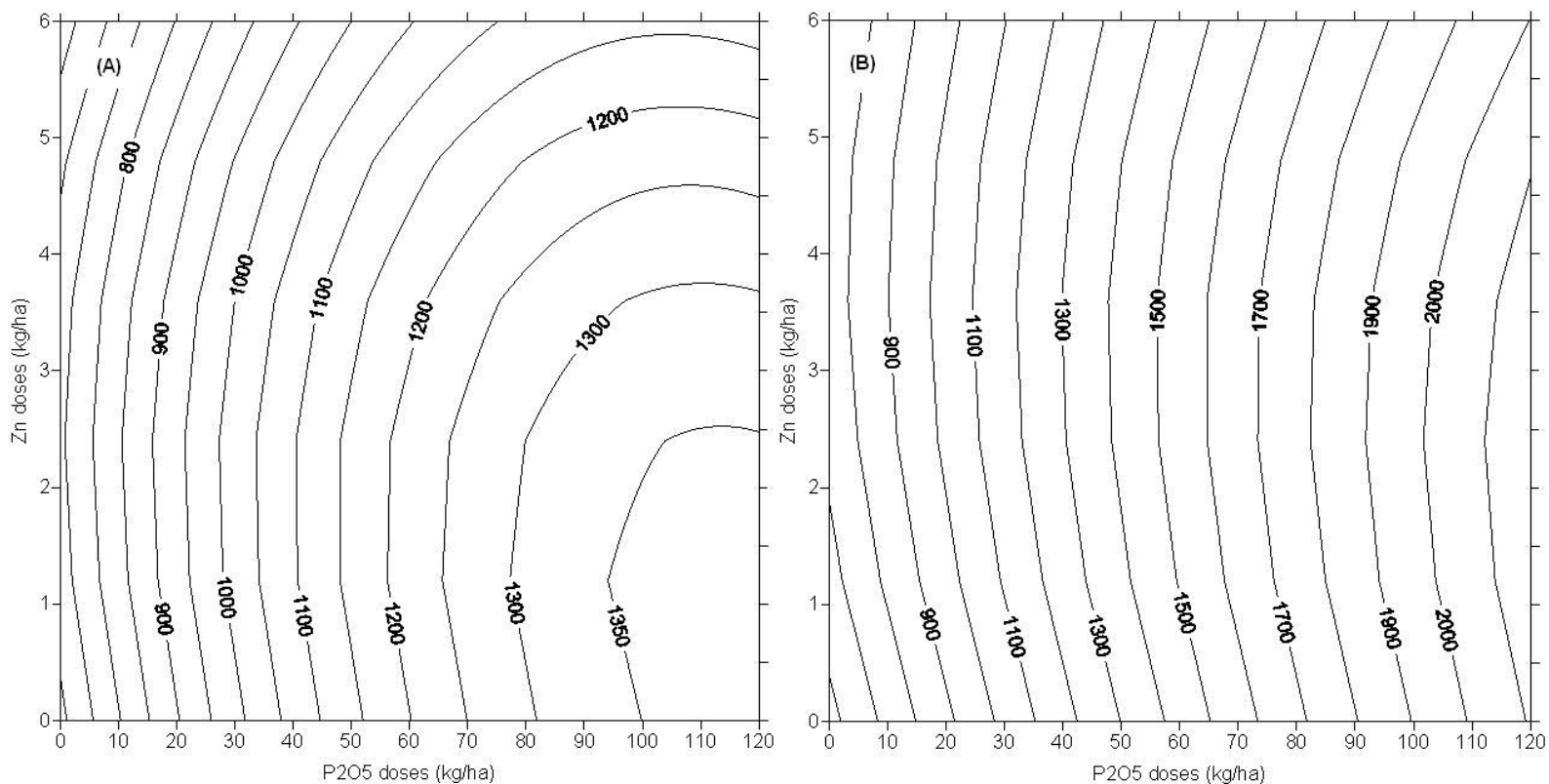

Figure 1. Technical yields of grains as a function of the application of $\mathrm{P}_{2} \mathrm{O}_{5}$ and zinc in 'BRS Guariba' (A), and 'BRS Aracê' (B) cowpea cultivars.

The production component responsible for maximum grain yields was the number of pods per plant, with values of 6 and 10 for the cultivars 'BRS Guariba' and 'BRS Aracê', respectively (Figures 2A and $2 \mathrm{~B}$ ). The mean correlation coefficient was 0.82

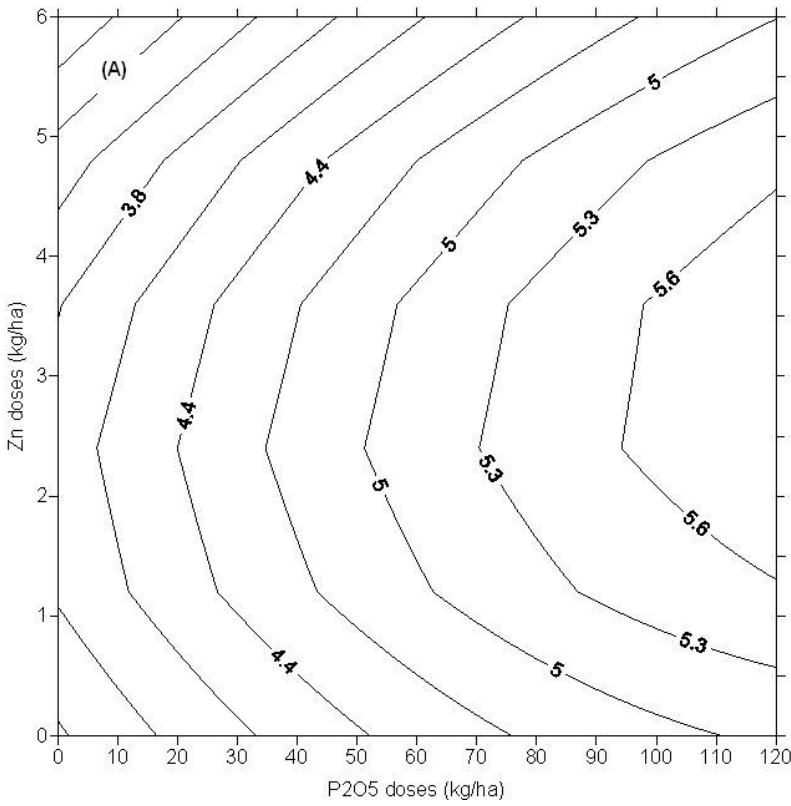

( $\mathrm{p}<0.01$ ). Phosphorus and zinc levels had no influence on production components, the number of grains per pod, and mass of one hundred grains, according to the data of variance analysis contained in Table 1.

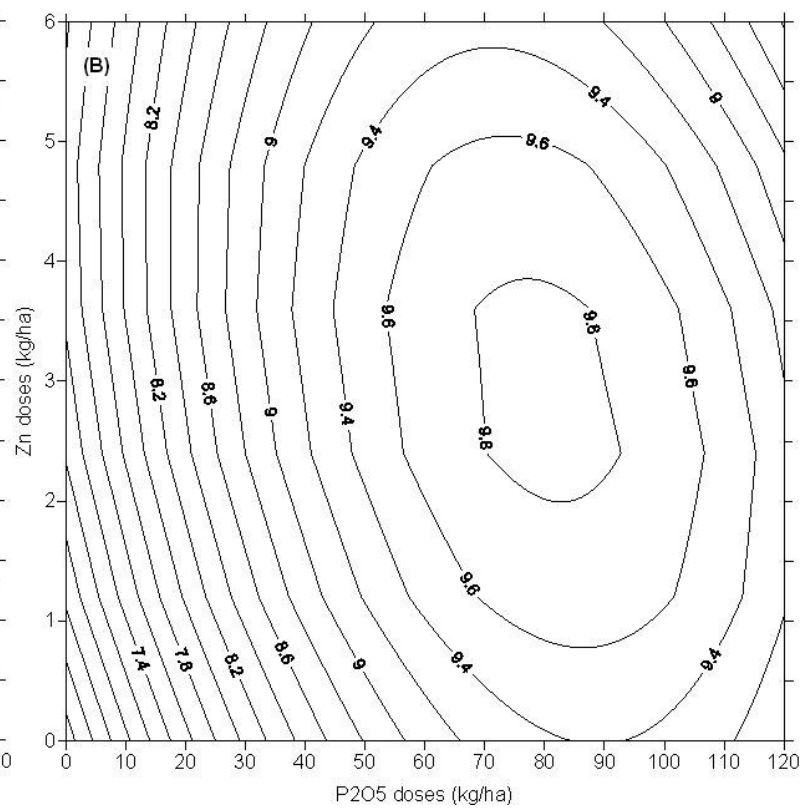

Figure 2. Number of pods per plant as a function of the application of $\mathrm{P}_{2} \mathrm{O}_{5}$ and zinc in 'BRS Guariba' (A) and 'BRS Aracê' (B) cowpea cultivars.

Cowpea grain yield highly increased as phosphorus and zinc doses added to the soil were raised (Figure 1). This evidences the crop's efficient response to these nutrients, which are presented in the soil at low levels evidenced by the results of soil chemical analysis before treatment application for the two cultivars.
A greater grain yield expression was observed for the cultivar 'BRS Aracê', probably due to its greater maturation cycle, coinciding with flowering and pod formation out of the period of soil water stress (LINHARES et al., 2008). Several authors obtained similar results for cowpea and common bean, namely Silva, Resende, and Cintra (2001), 
Silva et al. (2010), Fonseca et al. (2011), Oliveira et al. (2011), Coutinho et al. (2014), and Carvalho et al. (2014).

The analysis of variance showed the existence of phosphorus $x$ zinc interaction $(p<0.01)$ for the number of pods per plant and grain yield, and the phosphorus doses showed different behavior in relation to the different zinc doses (Table 1). These results are similar to those obtained by Rosal (2013), and Mousavi, Galavi, and Rezaei (2012).

The adjusted grain yield equations for the two cowpea cultivars presented $\mathrm{R}^{2}=0.84$, and $\mathrm{R}^{2}=0.89$. These values can be considered high when it comes to biological phenomena, and it shows that $84 \%$ and $89 \%$ of the grain yield variation for 'BRS Guariba' and 'BRS Aracê', respectively, were as function of the levels of phosphorus and zinc applied. This fact is clarified by the quadratic polynomial equation shown in Figures 1A, 1B, 2A, and 2B. Phosphorus is observed to influence crop productivity more than zinc. This is evidenced by the greater curvature of the $\mathrm{P}_{2} \mathrm{O}_{5}$ factor line on the response surface.

Figures $1 \mathrm{~A}$ and $1 \mathrm{~B}$ show the grain yield isoquants from the production function. These isoquants evidenced the combinations between the $\mathrm{P}_{2} \mathrm{O}_{5}$ and zinc levels that resulted in the same grain yield (Figures 1A and 1B), or in the same number of pods per plant (Figures 2A and 2B). These combinations show that the higher the productivity, the lower the number of combinations, to the point where a single combination is obtained, corresponding to the maximum physical productivity, which in this case was $1,281 \mathrm{~kg} \mathrm{ha}^{-1}$, and 2,026 $\mathrm{kg} \mathrm{ha}^{-1}$ for cultivars 'BRS Guariba' and 'BRS Aracê', respectively.

\section{CONCLUSIONS}

Cowpea bean yield increased concomitantly with increasing phosphorus and zinc doses, reaching maximum values at doses of $118 \mathrm{~kg} \mathrm{P}_{2} \mathrm{O}_{5} \mathrm{ha}^{-1}$ and $120 \mathrm{~kg} \mathrm{P}_{2} \mathrm{O}_{5} \mathrm{ha}^{-1}$ of phosphorus, and $0.9 \mathrm{~kg} \mathrm{ha}^{-1}$ and $3.1 \mathrm{~kg} \mathrm{ha}^{-1}$ of zinc for 'BRS Guariba' and 'BRS Aracê' cultivars, respectively. The production component responsible for such increased productivity was the number of pods per plant, with values of 6 and 10 for 'BRS Guariba' and 'BRS Aracê', respectively.

\section{REFERENCES}

BENVINDO, R. N. Adubação fosfatada e potássica na nutrição e na produtividade de feijão -caupi, cultivado no município de Bom Jesus-PI. 2012. 61 f. Tese (Doutorado em Agronomia: Área de Concentração em Produção Vegetal) - Faculdade de
Ciências Agrárias e Veterinárias, Universidade Estadual Paulista "Júlio de Mesquita Filho", Jaboticabal, 2012.

CARVAlHO, J. J. et al. Produtividade e teores de nutrientes em grãos de feijão sob diferentes manejos do solo e da irrigação. Revista Brasileira de Agricultura Irrigada, Fortaleza, v. 8, n. 3, p. 296-307, 2014

COUTINHO, P. W. R. et al. Doses de fósforo na cultura do feijão-caupi na região nordeste do Estado do Pará. Revista Agro@mbiente, Boa Vista, v. 8, n. 1, p. 66-73, 2014.

EMPRESA BRASILEIRA DE PESQUISA AGROPECUÁRIA - EMBRAPA. Manual de análises químicas de solos, plantas e fertilizantes. Brasília, DF: Embrapa, 1999. 370 p.

FAGERIA, N. K. Adubação e nutrição mineral da cultura de arroz. 1. ed. Santo Antônio de Goiás, GO: EMBRAPA, 1984. 341 p.

FAGERIA, N. K. Níveis adequados e tóxicos de zinco na produção de arroz, feijão, milho, soja e trigo em solo de cerrado. Revista Brasileira de Engenharia Agrícola e Ambiental, Campina Grande, v. 4, n. 3, p. 390-395, 2000.

FONSECA, M. R. et al. Teor e acúmulo de nutrientes por plantas de feijão-caupi em função do fósforo e da saturação de bases. Revista de Ciências Agrárias, Belém, v. 53, n. 2, p. 195-205, 2011.

LINHARES, L. C. F. et al. Limitações nutricionais de três cultivares de caupi, submetidas a omissão de nutrientes, cultivadas em Gleissolo de várzea do Rio Pará. Revista de Ciências Agrárias, Belém, v. 49, n. 1, p. 101-113, 2008.

MOUSAVI, S. R.; GALAVI, M.; REZAEI, M. The interaction of zinc with other elements in plants: a review. International Journal of Agriculture and Crop Sciences, London, v. 4, n. 24, p. 1881-1884, 2012.

OLIVEIRA, G. A. et al. Resposta do feijão-caupi às lâminas de irrigação e às doses de fósforo no cerrado de Roraima. Revista Ciência Agronômica, Fortaleza, v. 42, n. 4, p. 872-882, 2011.

ROSAL, C. J. S. Doses de fósforo e zinco na cultura do feijão-caupi. 2013. 48 f. Tese (Doutorado em Agronomia: Área de Concentração em Produção Vegetal) - Faculdade de Ciências Agrárias e Veterinárias, Universidade Estadual Paulista "Júlio de Mesquita Filho", Jaboticabal, 2013. 
SAMPAIO, L. S.; BRASIL, E. C. Exigência nutricional do feijão-caupi. In: CONGRESSO NACIONAL DE FEIJÃO CAUPI, 2, 2009, Belém. Anais... Belém: Embrapa Amazônia Oriental, 2009. 1 CD-ROM.

SAS INSTITUTE. SAS/STAT User's guide, version 9.2. Cary, 2008. 584 p.

SILVA, A. J. et al. Respostas do feijão-caupi à doses e formas de aplicação de fósforo em Latossolo Amarelo. Acta Amazônica, Manaus, v. 40, n. 1, p. 31-36, 2010.

SILVA, E. B.; RESENDE, J. C. F.; CINTRA, W. B. R. Resposta do feijoeiro a doses de fósforo em solo arenoso. Revista Ciência Rural, Santa Maria, v. 31, n. 6, p. 973-977, 2001.

ZIMMERMANN, F. J. P. Estatística aplicada à pesquisa agrícola. 2. ed. Santo Antônio de Goiás, GO: Embrapa Arroz e Feijão, 2004. 402 p. 